\title{
Groundwater Characterization and Quality Assessment by using GIS and Geo Statistics from Pandalgudi Region, Virudhunagar District, Tamilnadu, India
}

\author{
A. V. Udayanapillai ${ }^{a}$, M. Kaliammal ${ }^{\text {b }}$ \\ ${ }^{a, b}$ P.G Studies and Research Centre, Department of Geology, V.O.Chidambaram College, India \\ avupillai@gmail.com,kaligeo86@yahoo.com
}

\begin{abstract}
Twenty four representative groundwater samples collected during pre-monsoon and post monsoon seasons in 2014 from Pandalgudi region, Viruthunagar district, Tamilnadu, were analyzed for various physicochemical parameters such as $\mathrm{pH}, \mathrm{TDS}, \mathrm{EC}$, Cations $\mathrm{Ca}^{2+}, \mathrm{Mg}^{2+}, \mathrm{Na}^{+}, \mathrm{K}^{+}$and Anions $\mathrm{HCO}_{3}^{-}, \mathrm{SO}_{4}^{-}, \mathrm{Cl}^{-} \mathrm{F}^{-}$and $\mathrm{NO}_{3}$. The GIS based, thematic iso-quality geospatial contour maps for the integrated parameters of cations $\mathrm{Ca}^{2+}-\mathrm{Mg}^{2+}, \mathrm{Na}^{+}-\mathrm{K}^{+}$and anions $\mathrm{HCO}_{3}^{-}-\mathrm{SO}_{4}^{-}-\mathrm{Cl}$, were generated by the software Arc GIS 10.1. The geo statistical evaluation such as Multiple Correlations, Principal Component Analysis and Cluster Analysis of groundwater quality parameters was carried out by the geo-statistics software 'PAST'. Further, the water quality parameters were illustrated with Gibbs and Piper method. Finally, water qualities of the study area are compared with BIS and WHO standards of drinking water and other standards such as livestock and irrigation purposes.
\end{abstract}

Keywords: Physico-Chemical parameters; Arc GIS 10.1; PAST; Gibbs; Piper; BIS; WHO; Drinking water; Livestock; Irrigation

\section{INTRODUCTION}

Groundwater is more vital distributed resources in the earth. Utilization and necessity of groundwater for agriculture, industries and domestic purposes are being increased in developing countries. Further, due to overgrowth of population, socio-economic development, swifting urbanization and environmental degradation, water stress has been emerged as a real threat for human lives (Kaliammal and Udayanapillai, 2016). Many places in the world have already been under severe water stress. Numerous researchers have reported their research on hydro geochemical studies of groundwater, not only in India, but also in various part of the world ((Kumaresan and Riyazuddin, 2006; Tatawat and Singh Chandel, 2007; Sadashivaiah et al., 2008; Semwal and Jangwan, 2009; Dinesh Kumar Tank and Singh Chandel, 2010; Biswajeet Pradhan and Saied Pirasteh, 2011; Senthil Kumar, et al., 2014; Shahidullah et al., 2000; Pradhan and Chandrasekharan et al., 2009; Nwankwoala and Udom 2011; Ahmed Al-ameri et al., 2012; Ghoraba and Khan et al., 2013; Ghulam Hussian, Abdullah Al-Zarah and Latif, 2014). The quality of groundwater is highly affected spatially and temporally by various factors such as lithology, aquifer chemistry, rock-water interaction and its circulation, microbial action, pollution and seawater intrusion (Udayanapillai et al, 2012). These complex processes which make various hydro geochemical characterization, occurring in wide range of lithology from the age of Archaean crystalline rock to Recent alluvium. Different lithological condition in India makes tremendous changes in the hydro geochemistry of groundwater (Chanda and Chakaraborty, 2001). Many villages centered on Pandalgudi region of Virudhunagar district are utilizing groundwater long time for domestic and irrigation purposes. Except one or two minor reports, no much research work has been concentrated previously on the above study area pertaining to geochemistry of groundwater. Due to the welfare of the society of the study area, an attempt has been made in this paper to evaluate the geochemical characterization of groundwater utilizing GIS based techniques and geo statistical evaluation.

\section{STUDY AREA}

The study area is located above the Vaippar river basin and bounded with an aerial distance between 90 sqs $\mathrm{Km}$, centered on Pandalgudi town. The area falls in the survey of India Toposheet no 58/K3, prepared in the scale of 1:63360. It lies between the latitude from N $9^{\circ} 15^{\prime}$ to $\mathrm{N} 9^{\circ} 30^{\prime}$ and longitudes 


\section{A. V. Udayanapillai \& M. Kaliammal}

from $\mathrm{E} 78^{\circ} 0^{\prime}$ to $\mathrm{E} 78^{\circ} 15^{\prime}$ (Figure. 1). The area has been well connected with national and state highway road net work. The topography of the study area is generally flat and plain with devoid of any hill outcrop. It has the maximum elevation of $82 \mathrm{~m}$ from the MSL. Drainage patterns are dendritic and the drainage slope directions are generally facing towards south and south east direction and merge into the Vaippar river basin located at the south. The area generally experiences tropical climate and receives an average rainfall of $700 \mathrm{mms}$ per annum influenced by south west and north east monsoons. Lake irrigation and well irrigation is generally practiced in most part of the area.
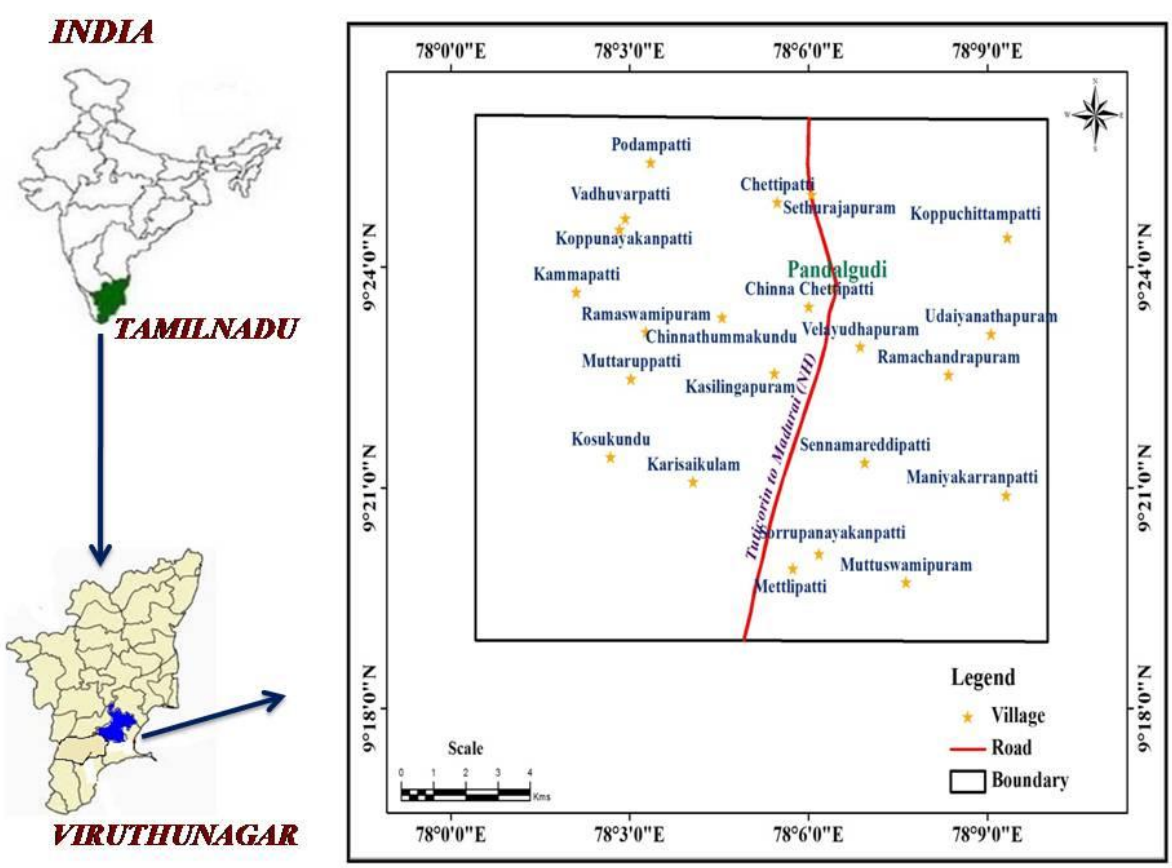

Fig1. The Location map of the study area

\subsection{Geology}

Proterozoic formation is the basement rocks which consist of quartzite, crystalline limestone, calcgranulite, hornblende - biotite gneiss, charnockite or pyroxene granulite, granite and pegmatite (Narayanasamy and Purnalakshmi, 1967). Weathered, a fissured cracks, shear zones and joints in the basement rock act as a good groundwater potential zone in the study area. Proterozoic formation is overlained by a thick calcrete with a thickness of $1.20 \mathrm{~m}$ which is believed to be the age of Holocene to Pleistocene deposits. The calcrete is overlained by the Recent alluvium of black soil and detached batches of red sandy loamy soil. The general stratigraphy of the study area are shown Table 1.I

Table1. Stratigraphical Succession in and around Pandalgudi area

\begin{tabular}{|c|l|l|}
\hline \multicolumn{2}{|c|}{ Age } & \multicolumn{1}{c|}{ Stratigraphy } \\
\hline \multicolumn{2}{|c|}{ Recent (1500 year) } & Black cotton soil, Red soil, Sandy loamy soil and Calcrete, as Cap rocks \\
\hline \multirow{0}{0}{} & $520 \mathrm{Ma}$ & Pink granites, White granites and Pegmatites \\
\cline { 2 - 3 } & $550 \mathrm{Ma}$ & Charnockite (With bands of Pyroxene granulites and intrusive of Pink granite veins) \\
\cline { 2 - 3 } & $>2000 \mathrm{Ma}$ & $\begin{array}{l}\text { Hornblande Biotite gneisses with enclaves of calc-silicate rocks, veins of crystalline limestone } \\
\text { band. }\end{array}$ \\
\hline \multirow{2}{0}{} & &
\end{tabular}

Table2. Average water quality parameters of two seasons in which all values in $\mathrm{mg} /$, except EC its $\mu \mathrm{S} / \mathrm{Cm}$

\begin{tabular}{|l|l|l|l|l|l|l|l|l|l|l|l|l|l|l|l|l|}
\hline S.No & Village & Latitude & Longitude & $\mathrm{Ca}$ & $\mathrm{Mg}$ & $\mathrm{Na}$ & $\mathrm{K}$ & $\mathrm{F}$ & $\mathrm{Cl}$ & $\mathrm{SO}_{4}$ & $\mathrm{CO}_{3}$ & $\mathrm{HCO}_{3}$ & $\mathrm{NO}_{3}$ & $\mathrm{pH}$ & $\mathrm{EC}$ & $\mathrm{TDS}$ \\
\hline 1 & Podampatti & 78.05 & 9.4166 & 12.4 & 10.56 & 140 & 4 & 0.17 & 32.54 & 38.62 & 38 & 648.8 & 0.8 & 7.5 & 1191 & 819.6 \\
\hline 2 & Ramalingapuram & 78.0666 & 9.4333 & 940 & 457 & 830 & 30 & 0.19 & 4013 & 736.21 & 0 & 98 & 1.1 & 7.5 & 12565 & 8632 \\
\hline 3 & Chidamparapuram & 78.0666 & 9.4333 & 71.6 & 14.53 & 13 & 11 & 0.23 & 140.3 & 46.37 & 10 & 331.6 & 0.3 & 7 & 888 & 435.3 \\
\hline 4 & Chettikurchi & 78.0833 & 9.4333 & 44.4 & 17.23 & 48 & 72 & 0.22 & 117.62 & 61.55 & 10 & 331.6 & 0 & 7.1 & 1003 & 654.9 \\
\hline 5 & Valvangi & 78.0833 & 9.4333 & 87.6 & 22.1 & 57 & 78 & 0.18 & 103.44 & 153.29 & 14 & 392.6 & 0.1 & 7.2 & 1283 & 850.1 \\
\hline 6 & Periyanayagipuram & 78.111 & 9.4333 & 227 & 86 & 285 & 40 & 0.19 & 766 & 1106 & 60 & 232 & 0 & 7.4 & 4080 & 2525 \\
\hline 7 & Ayankarisalkulam & 78.067 & 9.351 & 344 & 87.28 & 390 & 50 & 0.21 & 443.76 & 942.18 & 14 & 270.6 & 0.8 & 7 & 4063 & 2491 \\
\hline 8 & Kosukundu & 78.0333 & 9.357 & 41.2 & 25.99 & 55 & 9 & 0.24 & 75.02 & 74.4 & 14 & 197.4 & 2 & 7.2 & 799 & 490.2 \\
\hline
\end{tabular}


Groundwater Characterization and Quality Assessment by using GIS and Geo Statistics from Pandalgudi Region, Virudhunagar District, Tamilnadu, India

\begin{tabular}{|l|l|l|l|l|l|l|l|l|l|l|l|l|l|l|l|l|}
\hline 9 & Mutharpatti & 78.0519 & 9.3666 & 122 & 44 & 78 & 29 & 0.23 & 269 & 997 & 0 & 207 & 0 & 7.4 & 2265 & 880 \\
\hline 10 & Ramaswamipuram & 78.05 & 9.3833 & 112 & 45.72 & 68 & 21 & 0.23 & 141.8 & 57.79 & 0 & 475.8 & 0.1 & 7.1 & 1291 & 768.6 \\
\hline 11 & Chinnathummakundu & 78.0666 & 9.3833 & 30 & 55.17 & 575 & 5 & 0.18 & 429.58 & 526.67 & 10 & 661 & 1.2 & 7.1 & 3365 & 2674 \\
\hline 12 & Lakshmipuram & 78.0333 & 9.3833 & 97.2 & 15.48 & 16 & 15 & 0.15 & 75.08 & 53.3 & 10 & 282.8 & 1.2 & 7.1 & 822 & 478 \\
\hline 13 & Kanmaipatti & 78.0166 & 9.3833 & 158 & 88.25 & 274 & 26 & 0.19 & 273 & 713.82 & 10 & 417 & 0.8 & 7.1 & 2980 & 2051.8 \\
\hline 14 & Koppunayanpatti & 78.0333 & 9.408 & 38 & 31.83 & 102 & 70 & 0.24 & 245.24 & 103.75 & 14 & 295 & 0.4 & 7.3 & 1354 & 953.8 \\
\hline 15 & Vadhuvarpatti & 78.0333 & 9.411 & 249.2 & 122.2 & 110 & 6 & 0.2 & 429.58 & 431.26 & 10 & 270.6 & 0.5 & 7 & 2758 & 1832.2 \\
\hline 16 & Sethurajapuram & 78.0833 & 9.4166 & 75.6 & 31.83 & 23 & 8 & 0.16 & 32.54 & 157.88 & 14 & 173 & 0.12 & 7.3 & 791 & 484.4 \\
\hline 17 & Pandalgudi & 78.0833 & 9.4166 & 200 & 47 & 93 & 17 & 0.24 & 411 & 989 & 0 & 281 & 0 & 7.7 & 2745 & 1188 \\
\hline 18 & Koppuchittampatti & 78.155 & 9.407 & 61 & 43 & 38 & 11 & 0.21 & 43 & 990 & 0.26 & 366 & 24 & 7.9 & 1835 & 536 \\
\hline 19 & Maniyakkaranpatti & 78.155 & 9.3333 & 302 & 265.3 & 940 & 10 & 0.23 & 103.4 & 1345 & 10 & 404.8 & 1.3 & 7.1 & 5901 & 5918 \\
\hline 20 & Surruppanayakanpatti & 78.103 & 9.3333 & 215.6 & 28.91 & 49 & 20 & 0.21 & 174.34 & 62.47 & 10 & 205 & 3 & 7 & 1466 & 1081.9 \\
\hline 21 & Maravarperungudi & 78.1666 & 9.3833 & 3 & 10 & 132 & 3 & 0.19 & 113 & 73 & 1.75 & 366 & 0 & 8.4 & 936 & 799 \\
\hline 22 & Pungamarathupatti & 78.1666 & 9.3833 & 19 & 23 & 92 & 2 & 0.2 & 142 & 183 & 0.4 & 171 & 0 & 8.2 & 900 & 653 \\
\hline 23 & Mettlipatti & 78.0833 & 9.3333 & 70 & 67.82 & 39 & 9 & 0.19 & 131.8 & 77.89 & 10 & 356 & 2.4 & 7 & 1210 & 728.1 \\
\hline 24 & Muthuswamipuram & 78.1166 & 9.3166 & 38 & 26 & 635 & 110 & 0.24 & 440 & 475 & 0 & 720 & 48 & 7 & 3480 & 2715 \\
\hline
\end{tabular}

\subsection{Materials and methods}

Twenty four average representative groundwater samples from both open wells and dug wells collected during both pre monsoons and post monsoons periods during 2014 were analyzed by adopting the standard analytical procedure (APHA, 1998). Moreover, well inventory details such as location, geology, well shape and dimensions and depth of water table were also observed, while collecting the samples Physical parameters $\mathrm{pH}$, TDS and EC, cations $\mathrm{Ca}^{2+}, \mathrm{Mg}^{2+}, \mathrm{Na}^{+}$and $\mathrm{K}^{+}$, anions $\mathrm{HCO}_{3}{ }^{-}, \mathrm{SO}_{4}{ }^{-}, \mathrm{Cl}^{-}, \mathrm{F}^{-}$and $\mathrm{NO}_{3}{ }^{-}$of the groundwater samples were analyzed. The estimated parameters of water quality study such as TH, NCH, Na\%, EC, SAR, PI and TDS (Ragunath, 1996) are compared with experimental results of 12 parameters for characterization of groundwater quality.

The GIS based geospatial iso quality contour maps by using Arc GIS 10.1 software, for the integrated parameters of cations $\mathrm{Ca}^{2+}-\mathrm{Mg}^{2+}, \mathrm{Na}^{+}-\mathrm{K}^{+}$and anions $\mathrm{HCO}_{3}^{-}-\mathrm{SO}_{4}{ }^{-}-\mathrm{Cl}^{-}$are prepared by IDW interpolation technique and overlay analysis. Statistical evaluation of Multiple Correlation, PCA and Cluster analysis of groundwater quality parameters were carried out by using geo statical computer software programme by PAST. A computer programmed Aquachem. 4.0 was used for calculation and graphical representation of Gibbs, Piper and USSL diagrams. The characterization of groundwater qualities of the study area is compared with BIS (2012) and WHO (2011) drinking water standard and other standards of livestock (Ramakrishnan 1998) use and irrigation purposes (Richard 1954).

\section{RESULT AND DISCUSSION}

The average values of the analytical result of 12 parameters of 24 averages water samples of both premonsoon and post-monsoon are given in (Table. 2). The integrated parameters of $\mathrm{Ca}^{2+}-\mathrm{Mg}^{2+}$ and $\mathrm{Na}^{+}$ $-\mathrm{K}^{+}, \mathrm{HCO}_{3}^{-}, \mathrm{SO}_{4}^{-}$and $\mathrm{Cl}^{-}$are taken into consideration for the GIS based spatial evaluation study. The other parameters such as $\mathrm{F}^{-}, \mathrm{NO}_{3}^{-}, \mathrm{EC}$, TDS and $\mathrm{pH}$ are smaller in values. So, they are not considered for drawing iso-spatial maps.

\subsection{Calcium and Magnesium}

The analytical data onto the study area show the $\mathrm{Ca}^{2+}$ and $\mathrm{Mg}^{2+}$ contents varying from $3 \mathrm{mg} / \mathrm{l}$ to $940 \mathrm{mg} / \mathrm{l}$ and $10 \mathrm{mg} / \mathrm{l}$ to $457 \mathrm{mg} / \mathrm{l}$ respectively. The concentration of calcium in groundwater depends on the solubility of $\mathrm{CaCO}_{3}, \mathrm{SO}_{4}^{-}$and rarely Chloride (Biswajeet Pradhan and Saied Pirasteh, 2011). Magnesium is known to occur naturally to magnesium bearing minerals in the rocks (Gnanachandraswamy et al, 2014). The spatial distribution of integrated $\mathrm{Ca}^{2+}-\mathrm{Mg}^{2+}$ maps (Fig. 2a) indicate that Ramalingapuram, Ramaswamipuram, Koppuchittampatti, Ayankarisalkulam and Maniyakaranpatti wells show higher concentration (above 100ppm) of $\mathrm{Ca}^{2+}-\mathrm{Mg}^{2+}$ level in the study area. Dissolution of calc-granulite, crystalline limestone and weathering of other calc-alkaline metamorphic rocks such as Hornblende-biotite-gneiss, charnockite, granite and black soil causes for $\mathrm{Ca}^{2+}-\mathrm{Mg}^{2+}$ sources in the groundwater. This has been supported by many researchers (Garrels, 1976; Lakshmanan et al, 2003; Al-katheeri et al, 2009; Semwal and Jangwam, 2009; Chandrasekhar Reddy et al, 2012; Ayyandurai et al. 2011; Kaliammal and Udayanapillai, 2016). 


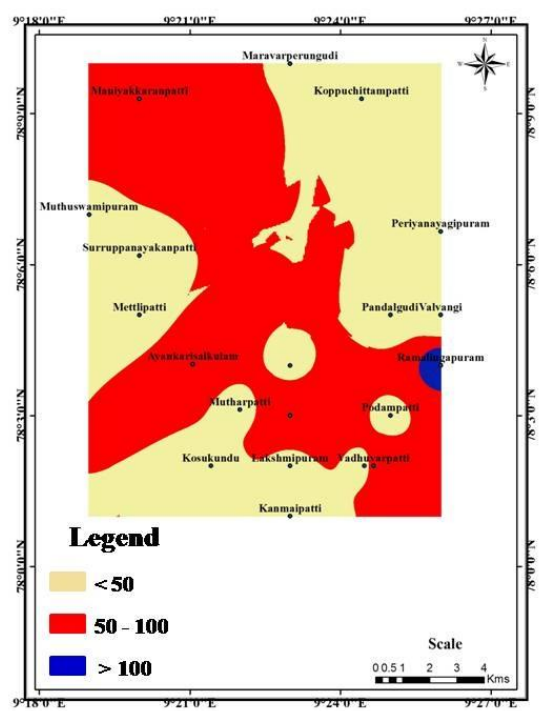

Fig2a. Integrated spatial distribution map of the Calcium and Magnesium

\subsection{Sodium and Potassium}

The analytical result of $\mathrm{Na}^{+}$and $\mathrm{K}^{+}$contents of the samples vary from $13 \mathrm{mg} / \mathrm{l}$ to $940 \mathrm{mg} / \mathrm{l}$ and $2 \mathrm{mg} / \mathrm{l}$ to $110 \mathrm{mg} / \mathrm{l}$ respectively. Sources of $\mathrm{Na}^{+}$are generally from halite, sea spray, hot spring, brine and some silicates or rare minerals such as (Nahcolite) (Ghorabha and Khan, 2013). But $\mathrm{Na}^{+}$and $\mathrm{K}^{+}$ sources in the study area is due to from the weathering of $\mathrm{Na}^{+}$and $\mathrm{K}^{+}$rich feldspar, hornblende, aegirine-augite and clay minerals montmorillite and Illite derived from the source rocks such as khondalite, charnockite, granite and black soil respectively. The spatial distribution integration map of $\mathrm{Na}^{+}$and $\mathrm{K}^{+}$(Fig. 2b) illustrate Ayankarisalkulam, Ramalingapuram, Sorruppanayakanpatti, Muthuswamipuram, Maniyakaranpatti and Chinnathummakundu villages which show higher concentration $\mathrm{Na}^{+}-\mathrm{K}^{+}$content $(>50)$ level in the study area.

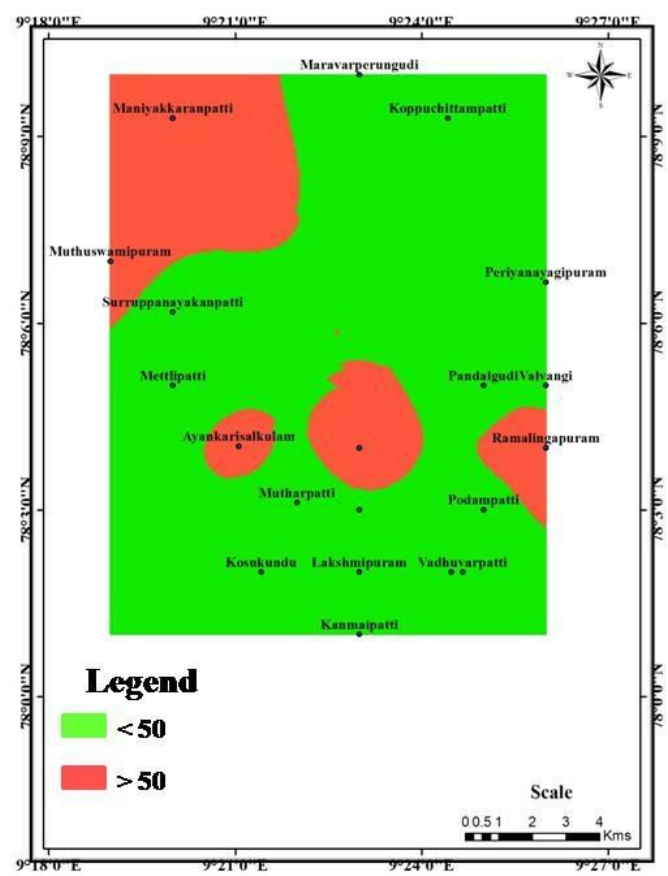

Fig2b. Integrated spatial distribution map of the Sodium and Potassium

\subsection{Bicarbonate, Sulphate and Chloride}

The concentration $\mathrm{HCO}_{3}{ }^{-}, \mathrm{Cl}^{-}$and $\mathrm{SO}_{4}{ }^{-}$contents in the samples vary from $171 \mathrm{mg} / \mathrm{l}, 38.62 \mathrm{mg} / \mathrm{l}$ and $32.54 \mathrm{mg} / \mathrm{l}$ to $720 \mathrm{mg} / \mathrm{l}, 990 \mathrm{mg} / \mathrm{l}$ and $4013 \mathrm{mg} / \mathrm{l}$ respectively. Sources of bicarbonate are obtained from the minerals calcite, dolomite and aragonite etc and the prime contributing rocks are crystalline limestone, calc granulite and calcrete. The dissolving $\mathrm{Ca}^{2+}$ and $\mathrm{HCO}_{3}{ }^{-}$ion from groundwater derived 
from the sources rocks of calc-alkaline igneous rocks form calcrete by evapotranspiration process (Udayanapillai et al, 2014). So, the occurrence of more calcrete deposits to indicate the evidence that groundwater is generally more alkaline in nature.

The higher $\mathrm{Cl}^{-}$content of groundwater may be attributed by soluble chloride from rock, sea water ingress (Sridhar et al, 2013) and black soil (Lakshmanan et al, 2003). The $\mathrm{Cl}^{-}$content of the study area is mainly obtained from rock sources and black soil. The sources of $\mathrm{SO}_{4}{ }^{-}$are generally obtained from the sulphur, sulphides, sulphates of heavy metals, gypsum, anhydrite and pyrite. Sulphate content of the study area is mainly obtained from rock sources. The integrated iso-quality geospatial maps of $\mathrm{HCO}_{3}{ }^{-}, \mathrm{Cl}^{-}$and $\mathrm{SO}_{4}{ }^{-}$illustrate Ramalingapuram and Periyanayakipuram villages which show higher $\mathrm{HCO}_{3}{ }^{-}, \mathrm{Cl}^{-}$and $\mathrm{SO}_{4}{ }^{-}$content (> 500) levels in the study area (Fig. 2c).

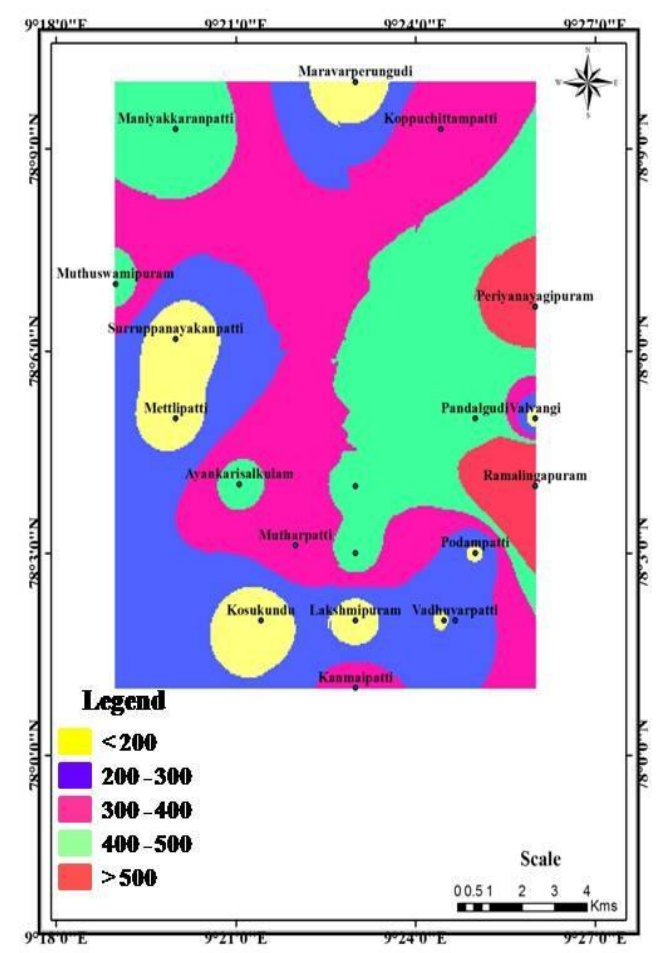

Fig2c. Integrated spatial distribution map of the Bicarbonate, Chloride and Sulphate

\section{Statistical Evaluation}

\subsection{Multiple Correlations}

Multiple correlations are a basic statistical tool to show the degree of dependency on geochemical variables with one another. It is commonly used to measure and establish the relationships between average variables. It also helps to distinguish the relevant hydro geochemistry facias. Numerous researchers have discussed the multiple correlation in geochemistry of groundwater (Hegde 2006; Srinivasamoorthy et al, 2010; Srivastava et al, 2012; Vandana Parth et al, 2011; Akpah et al, 2013; Gomaa et al, 2014; Emmanuel Morgan Attua et al, 2014; Asa Rani and Suresh Babu, 2008; Ameh, 2014; Belkhiri et al, 2011; Alhassan $\mathrm{H}$. Ismail et al, 2015). The multiple diagonally symmetrical linear correlation matrices of $\mathrm{Ca}^{2+}, \mathrm{Mg}^{2+}, \mathrm{Na}^{+}, \mathrm{K}^{+}, \mathrm{HCO}_{3}^{-}, \mathrm{SO}_{4}^{-}, \mathrm{Cl}^{-}, \mathrm{F}^{-}$and $\mathrm{NO}_{3}{ }^{-}, \mathrm{pH}, \mathrm{EC}$ and TDS of the study area samples are given in (Table. 3). Good correlations between the above variables are given in bold. The bivariate relation between the variable $\mathrm{Ca}^{2+}, \mathrm{Mg}^{2+}$ vs EC, $\mathrm{Na}^{+}, \mathrm{K}^{+}$vs $\mathrm{EC}, \mathrm{HCO}_{3}^{-}, \mathrm{Cl}^{-}$vs EC, $\mathrm{Cl}^{-}$vs EC, $\mathrm{Ca}^{2+}$ vs $\mathrm{Mg}^{2+}$ and $\mathrm{Na}^{+}$vs $\mathrm{K}^{+}$generally show positive correlation (Fadoua Hamzaoui Azasa et al, 2009; Udayanapillai et al, 2012). The relationship of above variables in the study area also shows existing same positive correlation, except $\mathrm{HCO}_{3}{ }^{-}$vs $\mathrm{EC}$, which shows a very low degree of insignificant negative correlation $(\mathrm{r}=-0.09)$. The $\mathrm{Na}^{+}$and $\mathrm{K}^{+}$are mainly obtained from the weathering of calc-alkaline group of rocks and carbonate sources are mainly obtained from the per alkaline group of rocks. The correlation studies between TDS vs $\mathrm{Na}^{+}, \mathrm{Ca}^{2+}, \mathrm{Mg}^{2+}$ shows positive correlations which indicate that the combined operation of chemical weathering, groundwater movement and river basin recharge controlled the chemistry of groundwater in the study area. 


\section{A. V. Udayanapillai \& M. Kaliammal}

Table3. The multiple correlation matrix of water quality parameters

\begin{tabular}{|l|l|l|l|l|l|l|l|l|l|l|l|l|}
\hline 1 & $\mathrm{Ca}^{2+}$ & $\mathrm{Mg}^{2+}$ & $\mathrm{Na}^{+}$ & $\mathrm{K}^{+}$ & $\mathrm{F}^{-}$ & $\mathrm{Cl}^{-}$ & $\mathrm{SO}_{4}^{-}$ & $\mathrm{HCO}_{3}^{-}$ & $\mathrm{NO}_{3}^{-}$ & $\mathrm{pH}$ & $\mathrm{EC}$ & $\mathrm{TDS}$ \\
\hline $\mathrm{Ca}^{2+}$ & 1 & & & & & & & & & & & \\
\hline $\mathrm{Mg}^{2+}$ & 0.919 & 1 & & & & & & & & & & \\
\hline $\mathrm{Na}^{+}$ & 0.610 & 0.770 & 1 & & & & & & & & & \\
\hline $\mathrm{K}^{+}$ & 0.449 & 0.327 & 0.380 & 1 & & & & & & & & \\
\hline $\mathrm{F}^{-}$ & -0.001 & 0.004 & 0.102 & 0.277 & 1 & & & & & & & \\
\hline $\mathrm{Cl}^{-}$ & 0.932 & 0.857 & 0.587 & 0.508 & -0.055 & 1 & & & & & & \\
\hline $\mathrm{SO}_{4}{ }^{-}$ & 0.162 & 0.272 & 0.418 & -0.036 & 0.283 & -0.002 & 1 & & & & & \\
\hline $\mathrm{HCO}_{3}{ }^{-}$ & -0.338 & -0.199 & 0.305 & 0.096 & -0.060 & -0.223 & 0.026 & 1 & & & & \\
\hline $\mathrm{NO}_{3}{ }^{-}$ & -0.160 & -0.124 & 0.222 & 0.362 & 0.270 & -0.062 & 0.137 & 0.518 & 1 & & & \\
\hline $\mathrm{pH}$ & -0.081 & -0.068 & -0.143 & -0.262 & -0.096 & 0.048 & 0.022 & -0.161 & -0.047 & 1 & & \\
\hline $\mathrm{EC}$ & 0.939 & 0.951 & 0.812 & 0.480 & 0.033 & 0.925 & 0.299 & -0.094 & 0.007 & -0.047 & 1 & \\
\hline $\mathrm{TDS}$ & 0.895 & 0.962 & 0.884 & 0.448 & 0.029 & 0.869 & 0.276 & -0.028 & 0.006 & -0.083 & 0.979 & 1 \\
\hline
\end{tabular}

\subsection{Principal Component Analysis}

Because of the demand for a rapid and simultaneous comparison and correlation between all the chemical variables, PCA has been utilized by many early researchers, in groundwater studies (Anderson 1958; Wilks 1963; Chachadi and Mahapatra 1983). Many subsequent research works have also been discussed by many authors of the $21^{\text {st }}$ century (Prashant K. et al, 2015; Sridhar Kumar et al, 2014; Usman Nasiru Usman et al, 2014; Srivastava Yehia Ahmed Idris, 2013). The assumptions of PCA are mainly based on linearity, importance of mean and co-variance, dynamics of large variances and orthogonal lines of best fit to the data. The Eigen value, percentage of cumulative variance and component loading scores are the important function of PCA analysis. The PCA has been performed by using basic computer programme "PAST". The Eigen value, $\%$ of total variance, $\%$ of cumulative variance and selected 4 principal component loading scores values of parameter of the study area are given in (Tables. 4a-b).

Table4a. Principal components Eigen values variances cumulative variances

\begin{tabular}{|l|l|l|l|l|}
\hline PC & Eigenvalue & \% Variance & Cumulative variance & PCA Component \\
\hline 1 & 5.6555 & 47.13 & 47.13 & I EC + TDS \\
\hline 2 & 2.0408 & 17.01 & 64.137 & $\mathrm{II} \mathrm{SO}_{4}^{-}+\mathrm{EC}$ \\
\hline 3 & 1.2432 & 10.36 & 74.498 & ${\mathrm{III} \mathrm{HCO}_{3}^{-}+\mathrm{EC}+\mathrm{TDS}}^{-}$ \\
\hline 4 & 1.1555 & 9.63 & 84.127 & $\mathrm{IV} \mathrm{SO}_{4}^{-}+\mathrm{Na}^{+}+\mathrm{TDS}^{-} \mathrm{Cl}^{-}$ \\
\hline 5 & 0.9438 & 7.87 & 91.992 & \\
\hline 6 & 0.4291 & 3.58 & 95.568 & \\
\hline 7 & 0.3147 & 2.62 & 98.19 & \\
\hline 8 & 0.1435 & 1.19 & 99.386 & \\
\hline 9 & 0.0452 & 0.38 & 99.763 & \\
\hline 10 & 0.0265 & 0.22 & 99.984 & \\
\hline 11 & 0.0014 & 0.01 & 99.996 & \\
\hline 12 & 0.0001 & 0.0009 & 99.996 & \\
\hline
\end{tabular}

Table4b. Component loading score for 4 Principal Components

\begin{tabular}{|l|l|l|l|l|l|}
\hline PC & Parameters & $\begin{array}{l}\text { Component } \\
\text { loading score } \\
\text { PC 1 }\end{array}$ & $\begin{array}{l}\text { Component loading } \\
\text { score PC 2 }\end{array}$ & $\begin{array}{l}\text { Component loading } \\
\text { score PC 3 }\end{array}$ & $\begin{array}{l}\text { Component loading score } \\
\text { PC 4 }\end{array}$ \\
\hline 1 & $\mathrm{Ca}^{2+}$ & -2.04 & 0.03 & -0.10 & -0.35 \\
\hline 2 & $\mathrm{Mg}^{2+}$ & -2.58 & -0.02 & -0.07 & -0.04 \\
\hline 3 & $\mathrm{Na}^{+}$ & -1.87 & -0.28 & -0.27 & $\mathbf{0 . 4 4}$ \\
\hline 4 & $\mathrm{~K}^{+}$ & -2.71 & -0.10 & 0.01 & -0.06 \\
\hline 5 & $\mathrm{~F}^{-}$ & -2.96 & -0.04 & -0.03 & -0.02 \\
\hline 6 & $\mathrm{Cl}^{-}$ & -1.03 & -0.10 & -0.57 & $\mathbf{- 0 . 8 0}$ \\
\hline 7 & $\mathrm{SO}_{4}^{-}$ & -0.43 & $\mathbf{2 . 0 2}$ & -0.06 & $\mathbf{0 . 5 8}$ \\
\hline 8 & $\mathrm{HCO}_{3}^{-}$ & 0.15 & -0.80 & $\mathbf{1 . 6 9}$ & 0.15 \\
\hline 9 & $\mathrm{NO}_{3}^{-}$ & -2.94 & -0.03 & -0.02 & -0.01 \\
\hline 10 & $\mathrm{pH}_{11}^{\mathrm{EC}}$ & -2.89 & -0.05 & -0.01 & -0.02 \\
\hline 12 & $\mathrm{TDS}$ & $\mathbf{1 2 . 3 7}$ & $\mathbf{0 . 7 0}$ & $\mathbf{0 . 3 2}$ & -0.39 \\
\hline
\end{tabular}

The scree plot based on PCA and components and Eigenvalues with variances are given in (Fig. 3). Many authors represent the scree plot of physico-chemical parameter of groundwater chemistry (Ayeni and Soneye, 2013; Alhassan H. Ismail et al, 2014). It could be observed from the table 4 that percentage of variance contribution to 4 PCA components are having the variance between $47.13 \%$, $17.01 \%, 10.36 \%$ and $9.61 \%$ respectively. The principal component factors are selected above the 
value of 1.0 Eigen values. Cumulatively, the 4 PCA components account for $84.13 \%$ of total variance. From the component loading on the parameter (Fig. 3), it could be seen that each component is primarily associated with only a few parameters and they are given as follows; I Component - EC + TDS; II Component $-\mathrm{SO}_{4}{ }^{-}+\mathrm{EC}$; III Component $-\mathrm{HCO}_{3}{ }^{-}+\mathrm{EC}$ and TDS; IV Component $-\mathrm{SO}_{4}{ }^{-}+$ $\mathrm{Na}^{+}+$TDS and $\mathrm{Cl}^{-}$. The first principal component weighed on positive direction of variable axis with the positive loading score of 12.37 and 6.95 for the parameters EC and TDS respectively. This contributes maximum $47.13 \%$ of total variance between the parameter. The second PCA component accounts for $17.01 \%$ of variance and is loaded onto $\mathrm{SO}_{4}{ }^{-}$and $\mathrm{EC}$ with positive component loading values 2.02 and 0.70 respectively. The third PCA components contribute to the variance between $10.36 \%$ and are loaded into the parameters of $\mathrm{HCO}_{3}^{-}$, EC, TDS and $\mathrm{Cl}^{-}$with highest positive and negative loading values of $1.69,0.32,-0.86$ and -0.57 respectively. The fourth PCA component accounts for the variance between $9.63 \%$ and is loaded with parameters of $\mathrm{SO}_{4}^{-}, \mathrm{TDS}, \mathrm{Na}^{+}$and $\mathrm{Cl}^{-}$ with the loading value of $0.58,0.56,0.44$ and -0.8 respectively.

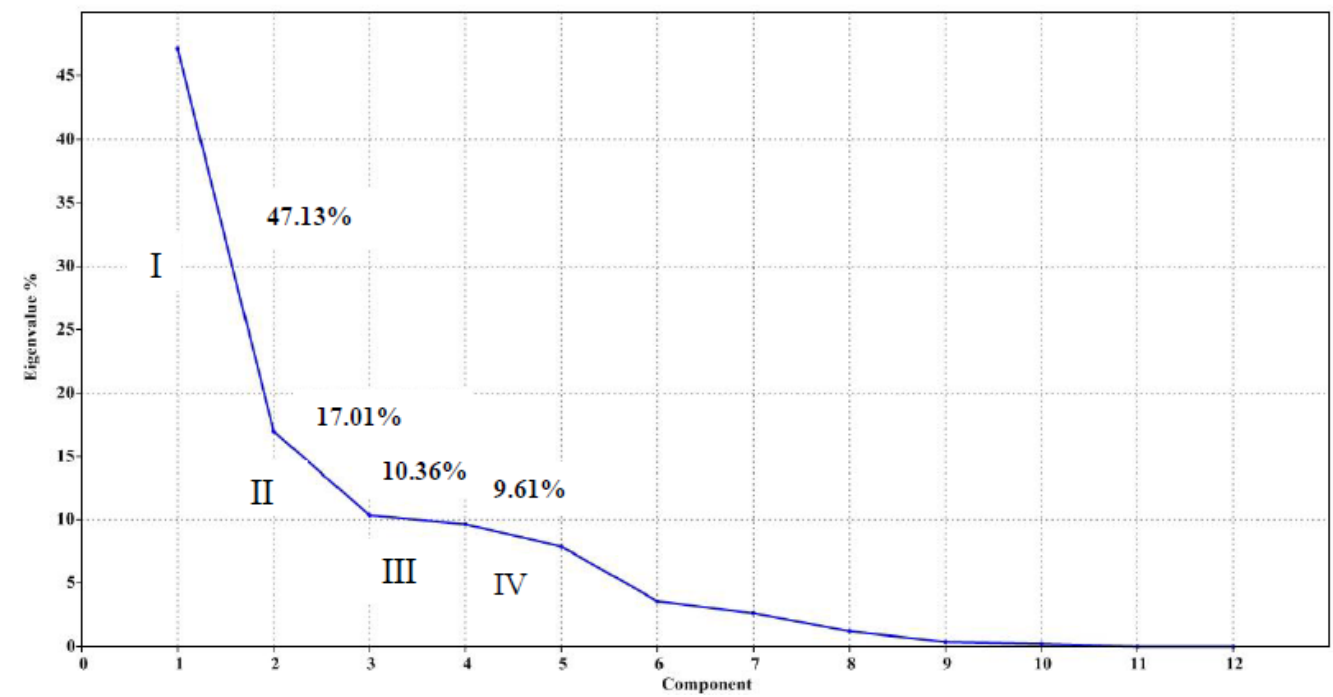

Fig3. Scree plot of PCA components

\subsection{Cluster Analysis}

Cluster analysis is a statistical technique which is used to classity cases of groups that are relatively homogenous within themselves and heterogeneous between each other, on the basis of a defined set of variables. These groups are called as clusters. When compared to principal component analysis, it is observed that PCA loading gradually decrease in each component and does not provide a direct relation to any other ion or two set of individual families. But cluster analysis points out a direct relation between parameters. Using diagonally symmetrical correlation matrices and arithmetic averaging of correlation coefficient, cluster analysis has been performed using the methodology by (Davis 1973). Many subsequent researchers discussed the cluster analysis of geochemical parameters of groundwater's in $21^{\text {st }}$ century (Usman Nasiru Usman et al, 2014; Yehia Ahmed Idris, 2013; Prashant K. Srivastave et al, 2015; Petr Praus, 2007; Gomaa et al, 2014; Alhassan H. Ismail et al, 2015). The cluster analyses of geochemical parameters of the study area are performed for 2 purposes of study, such as;

1. Ionic clusters concentration on the elements of geochemistry of groundwater

2. Aerial grouping of cluster of concentration of elements of the groundwater samples in the study area.

The following average parried groups of ionic clusters of geochemical parameters is obtained in the present studies

Ionic cluster

1. $\mathrm{SO}_{4}^{-}, \mathrm{F}^{-}, \mathrm{K}^{+}, \mathrm{Na}^{+}$

2. TDS, $\mathrm{EC}, \mathrm{Mg}^{2+}, \mathrm{Ca}^{2+}, \mathrm{Cl}^{-}$

3. $\mathrm{NO}_{3}^{-}, \mathrm{HCO}_{3}^{-}$

4. $\mathrm{pH}$
Similarity or correlation coefficient of cluster

0.20

0.90

0.50

0.05 


\section{A. V. Udayanapillai \& M. Kaliammal}

The hierarchical tree cluster or dendrogram of ionic concentration of geochemistry of groundwater is shown in the diagram (Fig. 4a) and the degree of similarity or significance is established as the low negative values of -0.44 . The aerial grouping distribution of elemental concentration of geochemical parameters of groundwater samples of the study area is shown in the dendrogram, through Ward's minimum variance method or Euclidean method (Fig. 4b). The aerial distribution dendrogram shows the following four kinds of cluster which are as follows;

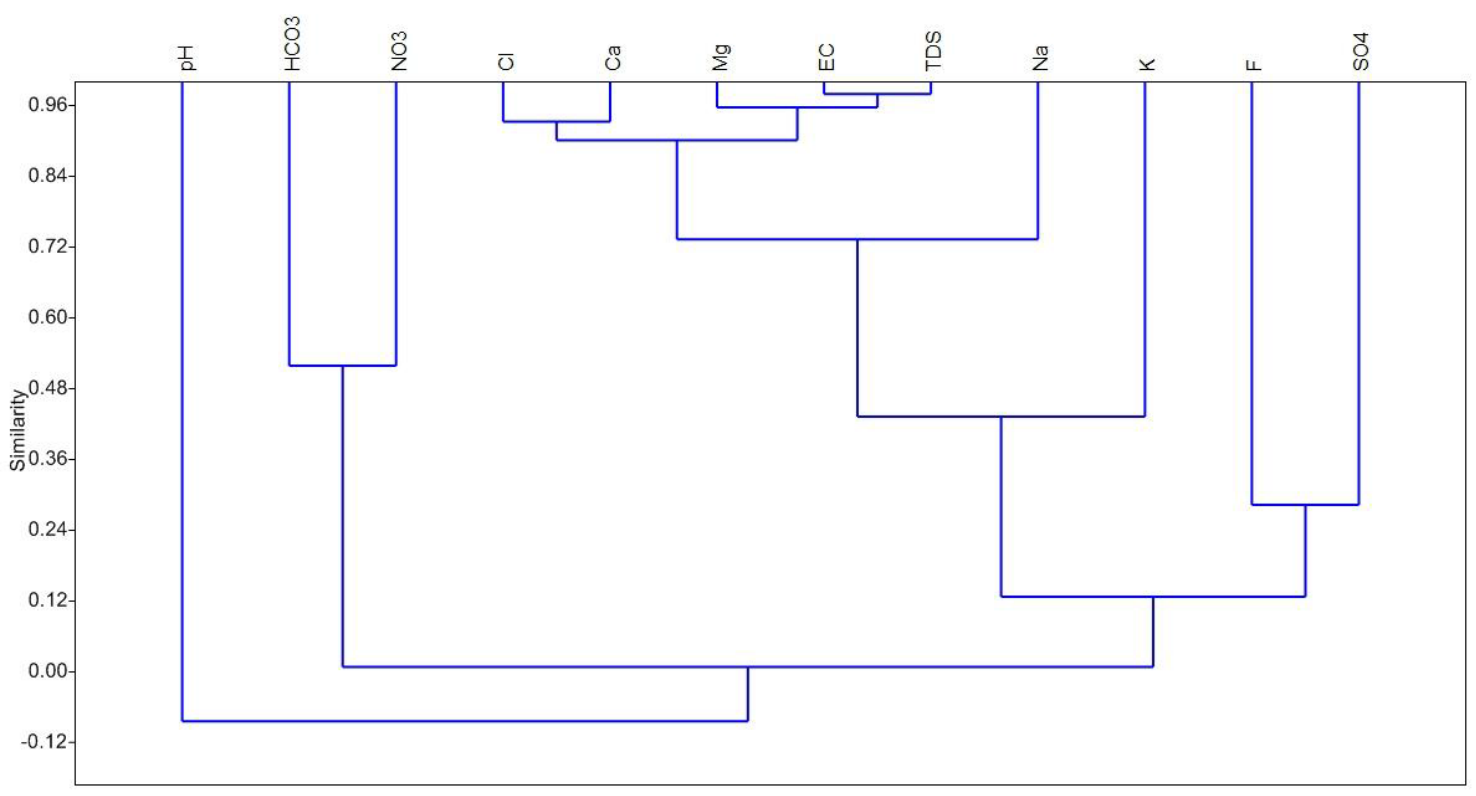

Fig4a. Dendrogram of ionic concentration of groundwater of the study area

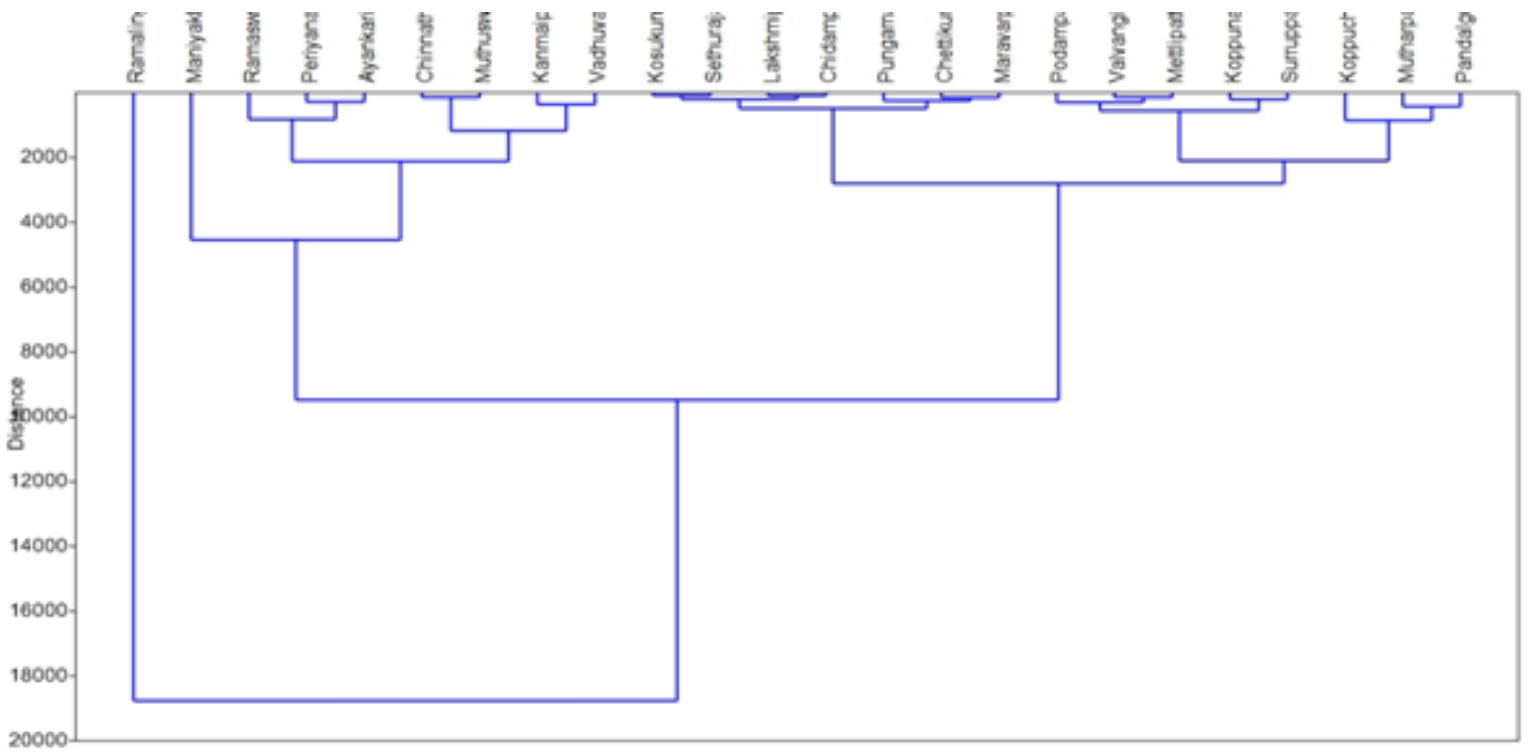

Fig4b. Aerial distribution of dendrogram cluster of geochemistry of groundwater

First cluster includes the sample locations of Koppuchittampatti, Mutharupatti and Pandalgudi villages. The second cluster consists of the sample locations of Podampatti, Valvangi, Mettlipatti, Koppunayakanpatti, Soruppanayakanpatti. The third cluster involves the sample locations such as Kosukundu, Sethurajapuram, Lakshmipuram, Chidambarapuram, Pungamarathupatti, Chettikurchichi and Maravarpaerungudi. The fourth cluster consists of the sample locations of Ramalingapuram, Maniyakaranpatti, Ramaswamipuram, Periyanayagipuram, Ayankarisalkulam, Chinnathummakundu, Muthuswamipuram, Kanmaipatti and Vaduvarpatti villages.

\subsection{Gibbs Machanism}

The mechanism controlling groundwater chemistry proposed by Gibbs (1970), established the close relationship between aquifer and water composition. This is established with cations and anions of groundwater such as $\mathrm{Cl}^{-} / \mathrm{Cl}^{-}+\mathrm{HCO}_{3}{ }^{-}$vs TDS and $\mathrm{Na}^{+}+\mathrm{K}^{+} / \mathrm{Na}^{+}+\mathrm{K}^{+}+\mathrm{Ca}^{2+}$ vs TDS. The cations and 
anions Gibbs diagram (Fig. 5a-b), for the average value of two seasons indicates the combined rock dominance and evaporation and crystallization dominance characters of mechanism that control the groundwater chemistry.
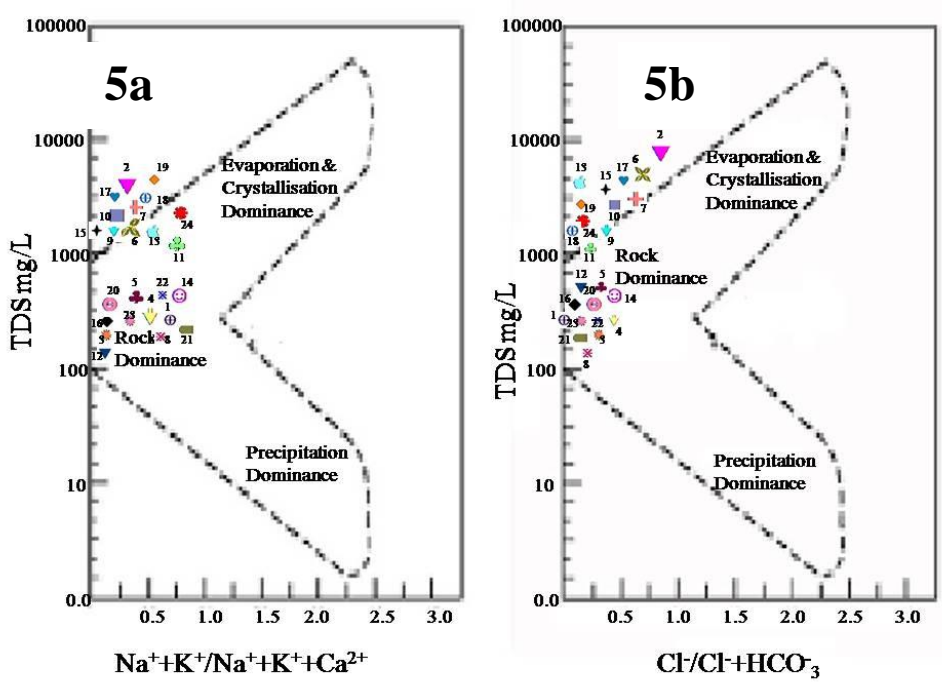

Fig5(a-b). Gibbs plots cations and anions for the average values of two seasons

Numerous researchers have observed such illustration of Gibbs mechanism from various regions (Masoud Eid AL-Ahmadi 2013; Srinivas et al., 2014; Ramesh and Thirumangai 2014; Senthilkumar et al., 2014; Udayanapillai et al., 2012 and 2014). The high TDS concentration indicates that there is a limited dilution process by soil leaching by surface water or meteoric water. The presence of more thickness of regolith calcrete profile in the study area also proves that evapo-transpiration and evaporation of groundwater is activity involved under tropical climate condition.

\subsection{Piper Diagram}

Piper diagram is widely used to understand problem of the geochemical faces of groundwater chemistry. The average values of cation and anions for two seasons plotted on the respective triangle field (Fig.6) are projected in the diamond shaped field by using the software (Aquachem 4.0)..
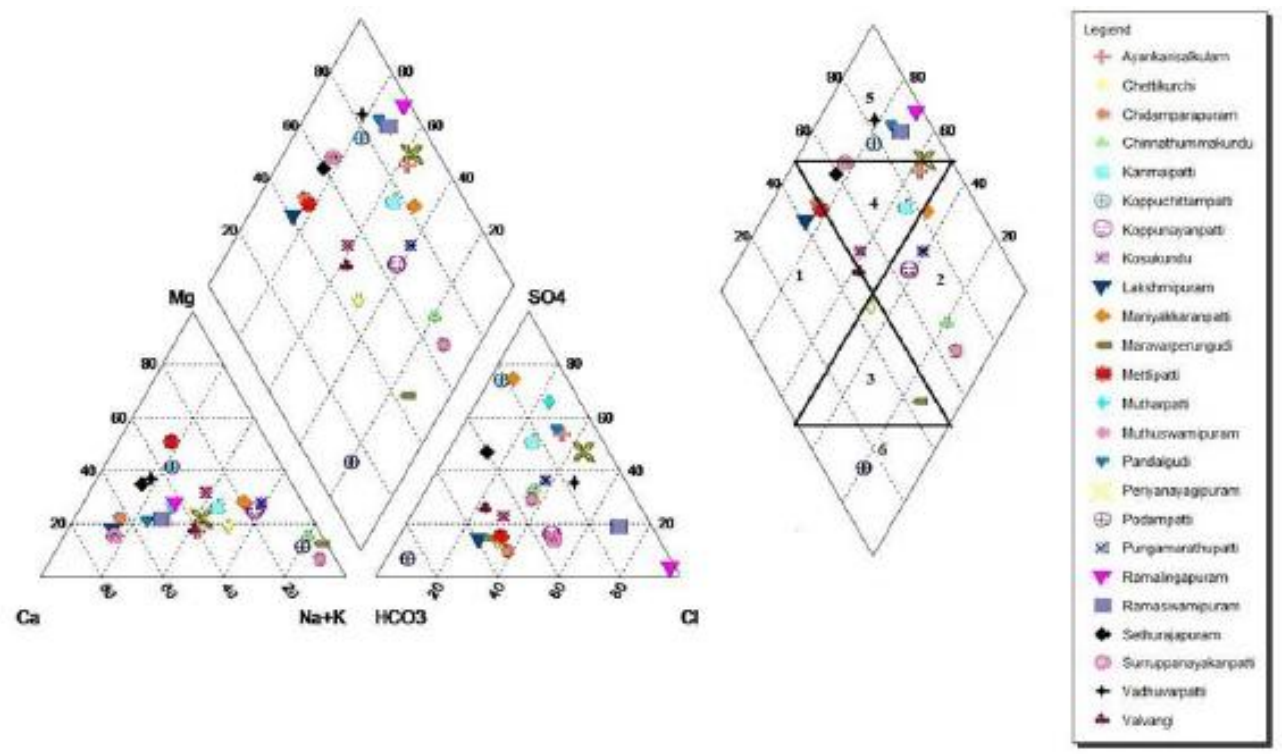

Fig6. Piper plots diagram in average value of the two seasons

The early researchers categorized the diamond shaped piper diagram into 9 geochemical facias (Hill 1999; Piper 1944; Walton 1970 and Dinesh Kumar and Singh 2010). Later, it is modified into 6 geochemical facias (Vasantha Vihar et al., 2010; Ahmed Al-ameri et al., 2012; Ghoraba and Khan 2013; Jafar Ahamed 2013 and Senthilkumar et al., 2014). The geochemistry of groundwater of the 
study area falls on the sub division of 5, 4, 2, 1,3 and 6 of diamond field indicates that $\mathrm{CaCl}(29 \%)$, Mixed $\mathrm{CaMgCl}(20 \%)$, $\mathrm{Nacl}(20 \%), \mathrm{CaHCO}_{3}(16 \%)$, Mixed $\mathrm{CaNaHCO}_{3}(8 \%)$ and $\mathrm{NaHCO}_{3}(4 \%)$ are important geochemical facias. Among the above 6 sub divisions, the predominance facias of groundwater of the study area are $\mathrm{CaCl}(29 \%)$, Mixed $\mathrm{CaMgCl}(20 \%)$ and $\mathrm{NaCl}(20 \%)$ types.

\subsection{Groundwater Quality Assessment}

Early researchers discussed the chemical quality standards for drinking, (BIS 1991; WHO 1973), livestock uses (Ramakrishna 1998) and irrigation uses (USDA diagram-Todd 1959). Subsequent research on the chemical quality of the study area is discussed related to the drinking water qualities standard (WHO, 2011; BIS, 2012) livestock standard (Ramakrishna 1998) and irrigation standard (Richards, 1954 and Wilcox, 1995 and Saharam Ashraf et al., 2011). Drinking water qualities of groundwater of the study area generally show within permissible limit of BIS and WHO, except serial number $(1,3,4,5,7,8,9,12,13,14,15,16,17,18,20,21,22$ and 23) which shows higher concentration than the permissible limit of WHO standard. Livestock use of water quality based on TDS (Ramakrishna 1998) is given as follows, Below 2500mg/l TDS - Fair; Below $3500 \mathrm{mg} / \mathrm{L}$ TDS Poor; Above $4500 \mathrm{mg} / \mathrm{L}$ TDS - Not satisfactory, As per the above classification, $75 \%$ of the study area is having low TDS which shows more suitable for live stock uses.

\subsection{Irrigation and Agricultural Quality}

The concentration of $\mathrm{Na}^{+}$is very important to classify the irrigation purpose. If the water rich in sodium is applied to soils, some of the sodium is taken up by clay which is in exchange gives up calcium and magnesium, thereby decreasing the permeability of the soil and it has a great effect of on plant growth (Shahidullah et al., 2000; Sadashivaiah 2008; Pradhan and Chandrasekharan 2009; Prabaharan et al., 2012; Erum Bashir et al., 2013; Shah and Mistry 2013) Sodium Adsorption Ratio (SAR) gives a clear idea about the adsorption of sodium by soil and the same has been calculated by using the following formula

$$
S A R=\frac{\mathrm{Na}}{[(\mathrm{Ca}+\mathrm{Mg}) / 2]^{\prime 2}}
$$

Where all ion concentration is expressed in EPM.
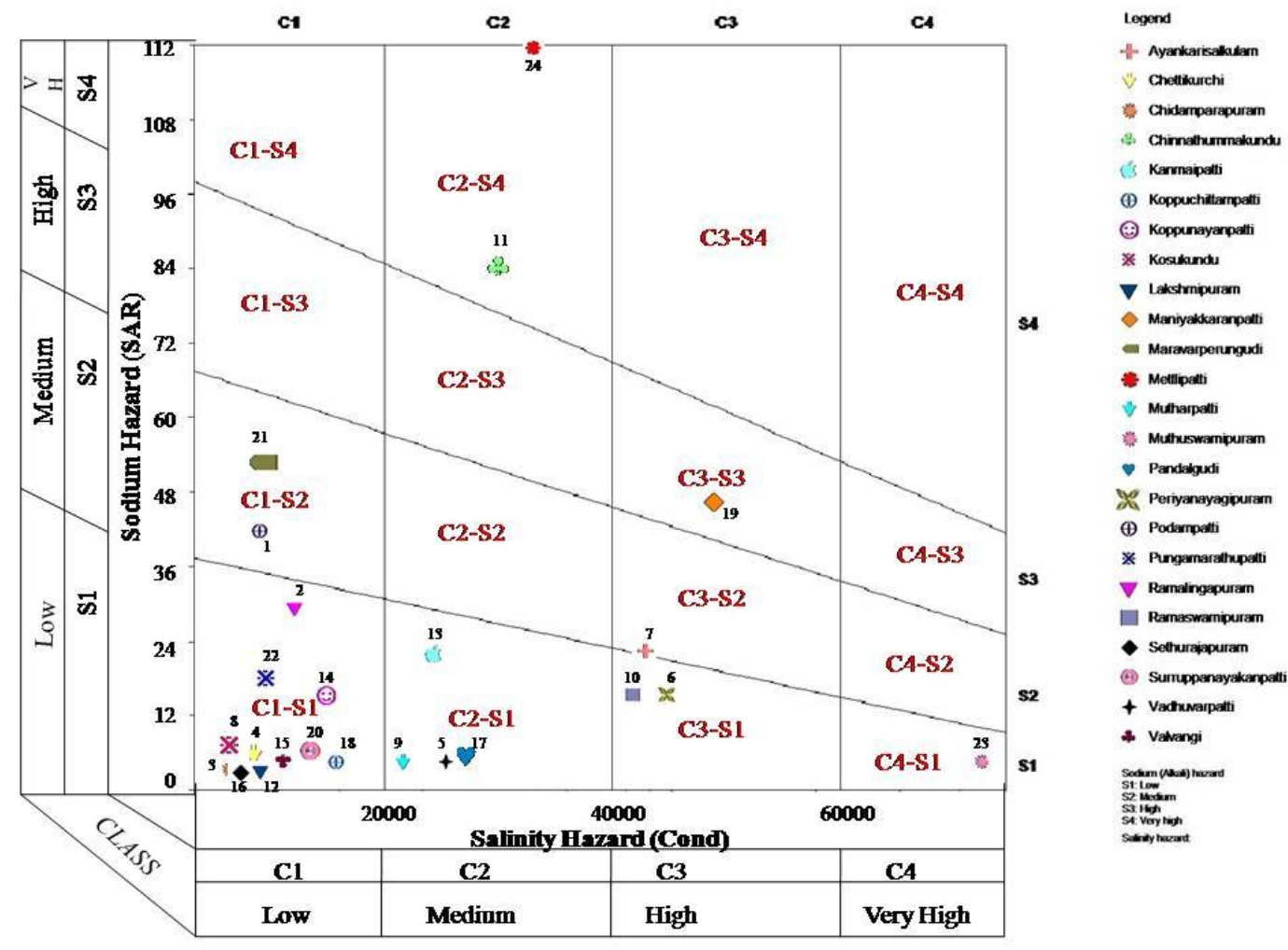

Fig7. USDA diagram plots in average value of the two seasons (Richard 1954) 
The Sodium Adsorption Ratio (SAR) parameter evaluates the Sodium hazard in relation to Calcium and Magnesium concentration. SAR values ranges of 2.13 to 112.2 , in the study area. The values greater than two indicate that ground water is unsuitable for irrigation purpose (Tatawat and Singh Chandel 2007; Rosalin Das et al., 2012; Ayuba et al., 2013). Only 9 ground water samples of this study area are showing higher SAR values, which are unsuitable as sources of water for irrigation. The utility of U.S Salinity diagram for (Fig. 7) irrigation is discussed by numerous researchers (USSL 1954; Sharaky et al., 2007; Umapathy 2011; Tripathi et al., 2012; Ahmed Al-ameri 2012; Kaveh Pazand and Ardeshir Hezarkhani 2012; Ikbal Husain et al., 2013). The average data plotted for two seasons of the study area indicate that 11 wells fall in $C_{1}-S_{1}$ and 2 wells fall in $C_{1}-S_{2}$ - excellent water quality, 4 wells in $\mathrm{C}_{2}-\mathrm{S}_{1}$ and 2 wells in $\mathrm{C}_{2}-\mathrm{S}_{4}$ - good water quality, 3 wells in $\mathrm{C}_{3}-\mathrm{S}_{1}$ and 1 well in $\mathrm{C}_{3^{-}}$ $\mathrm{S}_{3}$ - fair water quality and 1 wells in $\mathrm{C}_{4}-\mathrm{S}_{1}-$ bad water quality. The data plotted for the study area indicates that maximum water samples of the study area have excellent to good quality water for irrigation.

\subsection{Sodium Percentage}

Sodium in soil is considered as vital for determining groundwater suitability for irrigation purpose, because sodium reacts with soil to reduce its permeability and support little or no growth (Ayuba et al. 2013). Sodium salts in soil, besides affecting the growth of plants directly, also affect soil structure, permeability and aeration which directly assail plant growth (Singh et al. 2008).

The sodium in irrigation waters is usually denoted as percent sodium (Kumaresan and Riyazuddin 2006; Dinesh Kumar Tank and Singh Chandel 2010; Prabaharan et al., 2012; Rosalin Das et al., 2012; Erum Bashir et al., 2013) and can be determined using the following formula

$\% \mathrm{Na}=(\mathrm{Na}) \times 100 /\left(\mathrm{Ca}^{2+}+\mathrm{Mg}^{2+}+\mathrm{Na}^{2+}+\mathrm{K}^{+}\right)$

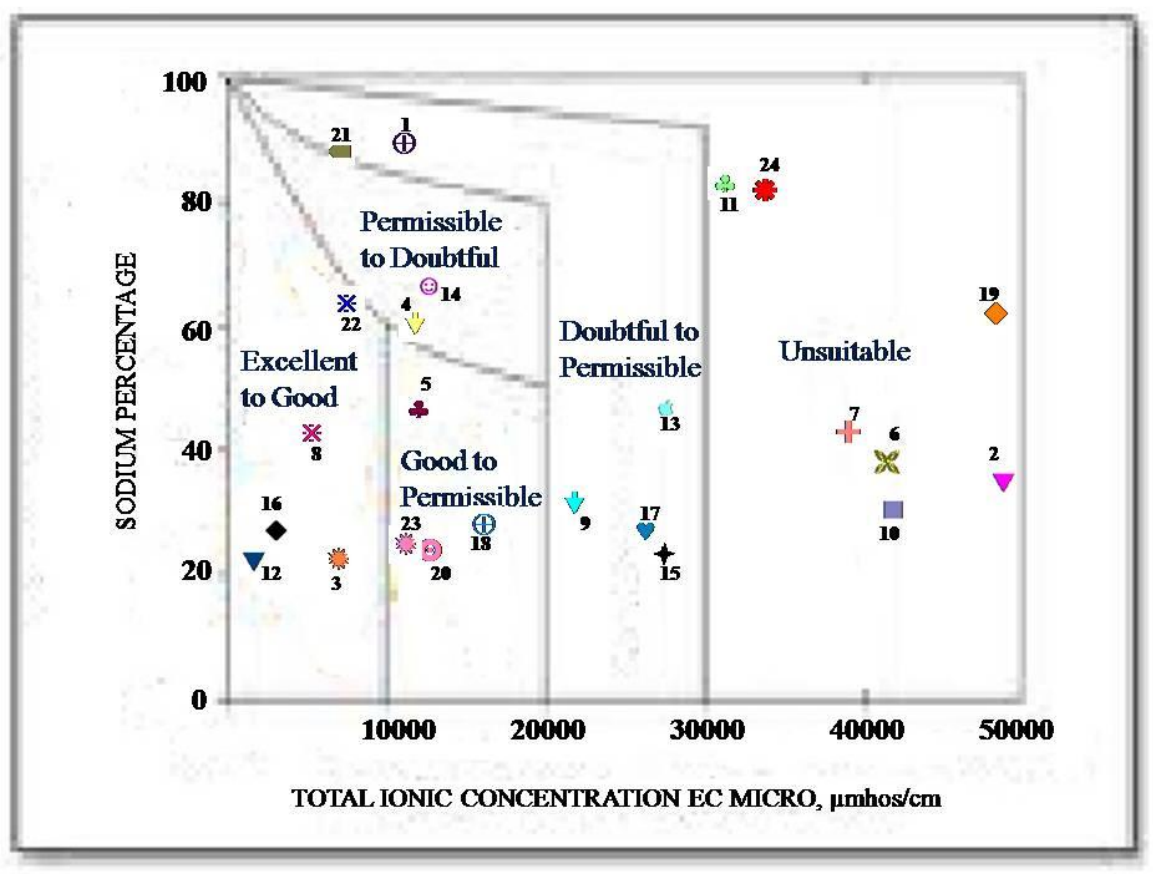

Fig8. Plot of the Sodium percentage and EC average value of the two seasons

The Na percentage of the study area ranges (Fig. 8) from $21.57 \%$ to $92.08 \%$. Na percentage greater than $35 \%$ in ground water is unsuitable for irrigation (Ayuba et al. 2013). Ground water samples 3, $12,15,16,17,18,20$ and 23 of the study area are unsuitable for irrigation purpose, whereas all other samples are suitable for irrigation purposes. In general, $67 \%$ of samples are suitable for irrigation purposes.

\subsection{Wilcox Diagram Result}

In the WILCOX diagram 1995, Electrical Conductivity and Sodium Percentage are used to classify the water for agricultural utility. Agricultural utility of groundwater sample based on Wilcox diagram plot, in various areas are discussed by numerous researchers (Kumaresan and Riyazuddin 2006; 
Sharaky et al., 2007; Sadashivaiah et al., 2008;Tatawat and Singh Chandel 2008; Dinesh Kumar Tank and Singh Chandel 2010; Umapathy 2011; Kaveh Pazand and Ardeshir Hezarkhani 2012; Rosalin Das et al., 2012; Ahmed Al-ameri et al., 2012; Tripathi et al., 2012; Ayyandurai et al., 2013; Ikbal Husain et al., 2013; Sridhar et al., 2013; Srinivas et al., 2014). This average data plot of study area for two seasons reveals that out of 24 samples, 5 water samples falling on the excellent to good, 4 Samples are falling on good to permissible, 3 samples are falling on permissible to doubtful limit, 5 samples fall in doubtful to permissible limit and 7 samples fall in unsuitable field to permissible. In general, all the samples are suitable for agricultural utility. Groundwater quality can be more enhanced for livestock and irrigation and drinking water uses by river basin recharge, landuse pattern plan for impounding of water in ayacuts, construction of percolation ponds and canals making from major rivers, constructions of series of check dams in the major drainages and rainwater harvesting.

\section{Conclusions}

The study area is a hard rock crystalline terrain which consists of calc alkaline group of rocks such as Hornblende-biotite gneiss, charnockite, granite and per alkaline group of rocks such as crystalline limestone and calc granulites. The GIS based evaluation of geochemistry of groundwater illustrated groundwater quality distribution of the study area. Statistical evaluated through correlation, PCA and cluster analysis illustrates the association of geochemical parameters and its areal distribution concentration in the study area. Gibbs mechanism reveals evaporation and rock dominance character controlling water chemistry. Geochemical evaluation through Piper analysis shows the predominance of $\mathrm{CaCl}(24 \%)$, mixed $\mathrm{CaMgCl}(20 \%)$ and $\mathrm{NaCl}(20 \%)$ rich faces. Groundwater samples generally show within the permissible limit of BIS and WHO drinking water standard except $\mathrm{pH}$ and $\mathrm{Cl}^{-}$. Based on USDA standard $67 \%$ of samples are suitable for irrigation purposes. Groundwater quality may be enhanced by river basin recharge land use pattern plan, construction of check dam in river, construction of percolation ponds and rain water harvesting in the weathered zone of hard rocks.

\section{ACKNOWLEDGEMENT}

Authors acknowledge with thanks to the authorities on V. O. Chidambaram Educational Institute, Tuticorin, for granting permission to publish this paper. Further, the authors are thankful to Tamilnadu State Government of India, for the Research fellowship provided to the author M. Kaliammal, for the preparation of this research paper.

\section{REFERENCES}

Anderson, P.W, Random-Phase Approximation in the Theory of Superconductivity. APS Journals Archive. 112 (1958) p. 6.

APHA, AWWA \& WEF, Standard methods for the estimation of water and waste water. American Public Health Association Washington (1998).

Al-Katheeri, E. S., Howari, F. M., Murad, A. A, Hydrogeochemistry and pollution assessment of quaternary-tertiary aquifer in the Liwa area United Arab Emirates. Environment Earth Science 59, (2009) p. 581-592.

Ahmed Al-ameri, Michael Schneider Naif, Abo Lohom, Silvio Janetz, Hydrochemical Characterization and Classification of Groundwaters in the Sana'a Basin, Yemen. International Journal of Environment and Resource (IJER) 1(1), (2012) p. 1-15.

Ayyandurai, R., Suresh, M., Venkateswaran, S, Evaluation of Groundwater for Irrigational Purposes in Cumbum Valley Theni District Tamilnadu, India. International Journal of Innovative Technology and Exploring Engineering (IJITEE) 2(3), (2013) p. 182-185.

Ayuba, R., Omonona, O. V., Onwuka, O. S., Assessment of Groundwater Quality of Lokoja Basement Area North - Central Nigeria. Journal of Geology Society of India 82, (2013) p. 413420.

Ayeni, A. O; Soneye, A. S. O., Interpretation of surface water quality using principal components analysis and cluster analysis. Journal of Geography and Regional Planning 6(4), ISSN: 20701845, (2013) p. 132-141.

Alhassan H. Ismail; Basim Sh. Abed; Shahla Abdul-Qader., Application of Multivariate Statistical Techniques in the surface water quality Assessment of Tigris River at Baghdad stretch, Iraq. Journal of Babylon University/Engineering Sciences 22(2), (2014) p. 1-13. 
Alhassan H. Ismail; Muntasir, A. H; Reem J. Channo., Groundwater Quality Assessment in Urban Area of Baghdad, Iraq, Using Multivariate Statistical Techniques. Engnerring and Technology Journal 33 (2), (2015) p. 463-476.

Bureau of Indian Standards (BIS)., Indian standard specification for drinking water, ISI 10500: New Delhi (1991).

Biswajeet Pradhan.; Saied Pirasteh., Hydro-Chemical Analysis of the Ground Water of the Basaltic Catchments: Upper Bhatsai Region, Maharastra. The Open Hydrology Journal 5, (2011) p. 5157.

Bureau of Indian Standard (BIS)., Indian Standard specification for drinking water Delhi BIS, IS 10500, (2012) p. 2-4.

Chachadi, A.G; Mahapatra, D.K., Use of principal Component Analysis in Hydro Chemical Interpretation, A Case Study, Proc. Vol Sem.. On Hydrological investigation during the last 25 years in India, Assn. of Hydrologists of India, (1983) p. 245-249.

Chadha, D. K; Chakraborty, D., Groundwater quality of India: The changing spectrum.. Journal of Everthing about Water (2001) p. 74-76.

Chandra Sekhar Reddy, L; Deshpande, S. M; Ramana Reddy, K. V; Aher, K. R., Hydro Geochemical Processes in the Groundwater Environment of Vemula area Kadapa District South India. International Journal of Recent Trends in Science and Technology 3(1), (2012) p. 18-24.

Davis J.C., Statistics and Data Analysis in Geology, John Wiley and Sons, New York, 890, (1973).

Dinesh Kumar Tank; Singh Chandel, C. P., Analysis of the Major Ion Constituents in Groundwater of Jaipur City. Journal of Nature and Scenice 8(10), (2010) p. 1-7.

Erum Bashir; Shahid Naseem; Tajnees Pirzada., Geochemical study of groundwater of Uthal and Bela areas, Balochistan and its appraisal for drinking and irrigation water quality. International Journal of Agr. \& Env 02, (2013) p. 1-13.

Fadoua Hamzaoui-Azaza; Rachida Bouhlila; Moncef Gueddari., Geochemistry of Fluoride and Major Ion in the Groundwater Samples of Triassic Aquifer (South Eastern Tunisia) Through Multivariate and Hydrochemical Sechniques, Journal of Applied Sciences Research 5(11), (2009) p. 1941-1951.

Gibbs, R. J., Mechanisms controlling world's water chemistry. Journal of Science 170, (1970) p. 1088-1099.

Garrels, R. M., A survey of low-temperature water-mineral reactions. In Interpretation of Envirnomental Isotope and Hydrochemical Data in Ground-Water Hydrology. Vienna International Atomic Energy Agency (1976) p. 65-84.

Ghulam Hussian; Abdullah I., Al-Zarah; Latif, M. S., Effect of Groundwater Composition on Mineral Composition of Agricultural Plants in the Vicinity of Drainage Canals in Al-Asha Oasis Saudi Arabia. Asian Journal of Plant Sciences 13 (2), (2014) p. 80-86.

Gomaa, M. A; El Naggar, I. M; Ali, I. M; Omar, J. A; El Shahat, M. F., Effect of surface water system on groundwater composition using geochemical modeling and geostatistical techniques, East Nile Delta (Case study)". International Journal of Advanced Research 2(5), ISSN: 23205407 (2014) p. 475-497.

Gnanachandrasamy, G; Ramkumar, T; Venkataramanan, S; Vasudevan, S; Chung, S. Y; Bagyaraj, M., Accessing groundwater quality in lower part of Nagapattinam district Southern India using hydrogeochemistry and GIS interpolation techniques. Applied Water Science (2014) p.1-17.

Hill, S. M; Mc Queen, K. G; Foster, K. A., Regolith carbonate accumulation in Western and Central NSW; Characteristics and Potential as an Exploration sampling medium, In; Taylor GM and Pain C.F eds. State of Regolith, Proc.of Regolith, CRC LEME, Perth., 98, (1999) p. 191-208.

Hedge, G. V., Evaluation of chemical quality of groundwater resource in Dharward districts Karnataka. Journal of Geological Society of India 67, (2006) p. 4-58.

Ikbal Husain; Jakir Husain; Mohammed Arif., Environmental impact of dyeing and printing industry of Sanganer Rajasthan (India). Turkish Journal of Engineering \& Environmental Science 37, (2014) p. 272-285. 
Jafar Ahamed, A; Loganathan, K; Ananthakrishnan, S., A comparative of groundwater suitability for drinking and irrigation purposes in Pugalur area Karur district Tamilnadu India. Journal of Archives of Applied Science Research 5(1), (2013) p. 213-223.

Kumaresan, M; Riyazuddin, P., Major ion chemistry of environmental samples around sub-urban of Chennai city. Journal of Current Science 91(12), (2006) p. 1668-1677.

Kannan, N; Sabu Joseph., Quality of Groundwater in the Shallow Aquifers of a Paddy Dominated Agricultural River Basin Kerala India. International Journal of Civil and Environmental Engineering 2(3), (2010) p. 160-178.

Krishnaraj Srinivasamoorthy; Kannusamy Vijayaraghavan; Murugesan Vasanthavigar; Subramanya Sarma; Sabarathinam Chidambaram; Paluchamy Anandhan; Rama Manivannan., Assessment of groundwater quality with special emphasis on fluoride contamination in crystalline bed rock aquifers of Mettur region Tamilnadu India. Arab Journal of Geoscience (2010) p. 1-12.

Kaveh Pazand; Ardeshir Herarkhani., Investigation of hydrochemical characteristies of groundwater in the Bukan basin Northwest of Iran. Journal of Applied Water Science 2, (2012) p. 309-315.

Kaliammal, M; Udayanapillai, A. V. GIS based evaluation on geochemical studies of groundwater in and around Pandalgudi region of Viruthunagar district Tamilnadu India. International Research Journal of Environment Sciences 5(2), (2016) p. 1-11.

Lakshmanen, E; Kannan, R; Kumar, M. S., Major ion chemistry and classification of hydrochemical processes of groundwater in a part of Kancheepuram District Tamilnadu India. Journal of Envirnomental Geosciences 10(4), (2003) p. 157-166.

Masoud Eid AL-Ahmadi., Hydrochemical chatacteristics and evaluation of groundwater quality in Wadi As Sab'an Weatern Saudi Arabia. International Journal of Scientific \& Engineering Research 4(1), (2013).

Narayanaswamy, S; Purna Lakshmi., Charnockitic Rocks of Tinnevelly District Madars. Journal of geological Society of India 8 (0), (1967) p. 38-50.

Nwankwoala, H.O; Udom, G. J., Hydrochemical Facies and Ionic Ratios of Groundwater in Port Harcourt Southern Nigeria. Research Journal of Chemical Sciences 1(3), (2011) p. 87-101.

Piper, A. M., A graphic procedure in the geochemical interpretation of water analysis. Journal of Transactions - American Geophysical Union 25, (1944) p. 914-923.

Petr Praus., Water quality assessment using SVD-based principal component analysis of hydrological data. Journal of Water SA 31(4), ISSN: 1816 - 7950, (2005) p. 417-422.

Pradhan, S; Chandrasekharan, H., Effect of Monsoon Rain on Quality of Groundwater for Irrigation in Gohana Block of Haryana. Journal of Agricultural Physics 9, (2009) p. 38-43.

Prabaharan, S; Manonmani, R; Ramalingam, M; Subramani, T., Groundwater Contamination due to Municipal Solid Waste Disposal in Salem City using GIS. International Journal of Earth Sciences and Engineering 5 (4), (2012) p. 696-702.

Prashant K. Srivastava; Dawei Han; Manika Gupta; Saumitra Mukherjee., Integrated framework for monitoring groundwater pollution using a geographical information system and multivariate analysis. Hydrological Sciences Journal 57(7), (2015) p.1453-1472.

Richards, L.A., Diagnosis and improvement of saline and alkali soils Agric Hand Book USDA Washington D.C, 60, (1954) p. 160.

Ragunath, H. M., Ground Water, 2nd Edition. New age, International (P) Limited Publisher New Delhi, (1996).

Ramakrishnan, S., Ground Water Chennai, Published by S. Ramakrishnan, (1998) p. 310.

Rosalin Das; Madhumita Das; Shreerup Goswami., Groundwater Quality Assessment around Talabasta Area Banki Sub-Division Odisha India. International Journal of Earth Sciences and Engineering 5(6), (2012) p. 1609-1618.

Ramesh, K; Thirumangai, V., Trace metals contamination of groundwater in and around Tannery industrial area of Pallavaram, Chennai city India. International Journal of Research in Engineering and Technology 3(5), (2014) p. 163-169.

Shahidullah, S. M; Hakim, M. A; Alam, M. S; Shamsuddoha, A. T. M., Assessment of Groundwater Quality in a Selected Area of Bangladesh. Pakistan Journal of Biological Sciences 3(2), (2000) p. 246-249. 
Sharaky, A. M; Atta, S. A; El Hassanein, A. S; Khallaf, K. M. A., Hydrogeochemistry of groundwater in the Western Nile Delta aquifers Egypt. $2^{\text {nd }}$ International Conference on the Geology of Tethys 19(21), (2007) p. 1-23.

Singh, A. K; Mondal, G. C; Kumar, S; Singh, T. B; Tewary, B. K; Sinha, A., Major ion Chemistry, weathering processes and water Quality assessment in upper catchment of Damodar River basin India. Journal of Environmental Geology 54, (2008) p. 745-758.

Sadashivaiah, C; Ramakrishnaiah, C. R; Ranganna, G., Hydrochemical Analysis and Evaluation of Groundwater Quality in Tumkur Taluk Karnataka State India. International Journal Environmental Research Public Health 5(3), (2008) p. 158-164.

Semwal, N; Jangwan, J. S., Major ion chemistry of river Bhagirathi and river Kosi in the Uttarakhand Himalaya. International Journal Chemistry Science 7(2), (2009) p. 607-616.

Sridhar, S. G. D; Kanagaraj, G; Mahalingam, S; Amaladas, P., Hydrochemical analysis of Groundwater between Sadras and Chinnakuppam, Kancheepuram District Tamilnadu India. Journal of Academia and Industrial Research (JAIR) 2(3), (2013) p. 160-166.

Shimaa M, Ghoraba; Khan, A. D., Hydrochemistry and Groundwater Quality Assessment in Balochistan Province Pakistan. IJRRAS 17(2), (2013) p. 185-199.

Shah, S. M; Mistry, N. J., Evaluation of Groundwater Quality and its Suitability for an Agriculture use in, District Vadodara Gujarat India. Research Journal of Engineering Sciences 2(11), (2013) p. $1-5$.

Sridhar Kumar, A; Shnakaraiahb, K; Raoc, P. L. K. M; Sathyanarayana, M,. "Assessment of water quality in Hussainsagar lake and its inlet channels using multivariate statistical techniques". International Journal of Scientific \& Engineering Research 5(9), ISSN: 2229 - 5518, (2014) p. 327-333.

Srinivas, Y; Hudson Oliver, D; Stanley Raj, A; Chandrasekar, N., Quality assessment and hydrogeochemical characteristics of groundwater in Agastheeswaram taluk, Kanyakumari district Tamilnadu India. Chin. Journal of Geochemistry 33, (2014) p. 221-235.

Senthikumar, G; Ramanathan, A. L; Nainwal, H. C; Chidambaram, S., Hydrogeochemical Characteristics and Evolution of Coastal Groundwater at Cuddalore Area Tamilnadu India. International Journal of Engineering Research and General Science 2(2), (2014) p. 235-240.

Todd, D. K., Groundwater Hydrology, John Wiley and Sons, Inc. New York., (1959) p. 336.

Tatawat,R. K; Singh Chandel, C. P., Quality of Ground water of Jaipur city, Rajasthan (India) and its Suitability for domestic and irrigation purpose. Applied Ecology and Environmental Research 6(2), (2007) p. 79-88.

Tripathi, A. K; Mishra, U. K; Ajay Mishra., Parul Dubey., Assessment of Groundwater Quality Gurh Tehseel, Rewa District, Madhya Pradesh, India. International Journal of Scientific \& Engineering Research 3(9), (2012) p. 1-11.

USSL., Diagnosis and improvement of saline alkali solis: Agriculture., Handbook, US department of Agriculture Washington DC, 160, (1954) p. 60.

Umapathy, S., A study on ground water quality of Neyveli area, Cuddalore district, tamilnadu. International Journal of Geomatics and Geosciences 2(1), (2011) p. 49-56.

Udayanapillai, A. V; Venkataraman, P; Jeyaranjeetham, J; Perumal, V., Geochemistry of Groundwater in and around Vilathikulam and Ottaipidaram Taluks, Thoothukudi District, Tamilnadu, India. Journal of Outreach 5, (2012) p. 113-116.

Udayanapillai, A. V; Selvam, S; Balasubramanian, T; Emi Princess Prasanna, A; Venkataraman, P; Manimaran, G; Sivasubramanian, P., Geochemistry of Groundwater in and around Petmanagaram, Thoothukudi district, Tamilnadu, India. Journal of Outreach III, (2014) p. 46-50.

Usman Nasiru Usman; Mohd Ekhwan Toriman; Hafizan Juahir; Musa Garba Abdullahi; Ali Auwalu Rabiu; Hamza Isiyaka., Assessment of Groundwater Quality Using Multivariate Statistical Techniques in Terengganu.. Journal of Science and Technology 4(3), (2014) p. 42-49.

Vasanthavigar, M; Srinivasamoorthy, K; Vijayaragavan, K; Rajiv Gandhi, R; Chidambaram, S; Anandhan, P; Manivannan, R; Vasudevan, S., Application of water quality index for groundwater quality assessment: Thirumanimuttar sub-basin, Tamilnadu, India. Journal of Environ Monit Assess (2010). 
Wilks, S.S., Multivariate statistical outliers. Sankhya A, 25, (1963) p. 407-426.

WHO., Guideline for Drinking Water Quality (Recommendations) [Z], 1, $2^{\text {nd }}$ ed., Geneva (1997).

WHO., Hardness in Drinking-Water: Background document for development of WHO Guidelines for Drinking-Water Quality, (2011) p. 11.

Wilcox, L. V., Classification and use of irrigation waters, US Department of Agriculture, Washington DC, (1995) p. 19. 